\title{
PENENTUAN WAKTU YANG TEPAT PADA PROSES STAINING DALAM PEMBUATAN PREPARAT HISTOLOGIS HATI
}

\author{
Ellyawati \\ Jurusan Biologi, FakultasMatematikadanIlmuPengetahuanAlam \\ Universitas Andalas, Padang, Sumatera Barat \\ Email : ellyawatimirwan@gmail.com
}

\begin{abstract}
ABSTRAK
Hematoxylin-Eosin merupakan salah satu jenis pewarnaan jaringan umum digunakan dalam pewarnaan jaringan seperti dalam pewarnaan jaringan hati. Penelitian ini bertujuan untuk mengetahui waktu yang tepat pada proses staining preparat histologi hati dan memudahkan mahasiswa-mahasiswa praktikum dan penelitian mengenai histologi hati. Pengamatan dilakukan dengan membandingkan preparat jaringan hati yang diwarnai menggunakan Hematoxylin-Eosin stain dengan tiga jenis waktu yang berbeda. Hasil penelitian menunjukkan bahwa penggunaan Hematoxylin selama 20 detik dan Eosin selama 20 detik memberikan hasil yang paling baik dibandingkan lama waktu lainnya sehingga didapatkan hasil preparat yang lebih baik.
\end{abstract}

Keyword : Hematoxylin, Eosin, Staining, Jaringan Hati

\begin{abstract}
ABSTRAK
Hematoxylin-Eosin merupakan salah satu jenis pewarnaan jaringan umum digunakan dalam pewarnaan jaringan seperti dalam pewarnaan jaringan hati. Penelitian ini bertujuan untuk mengetahui waktu yang tepat pada proses staining preparat histologi hati dan memudahkan mahasiswa-mahasiswa praktikum dan penelitian mengenai histologi hati. Pengamatan dilakukan dengan membandingkan preparat jaringan hati yang diwarnai menggunakan Hematoxylin-Eosin stain dengan tiga jenis waktu yang berbeda. Hasil penelitian menunjukkan bahwa penggunaan Hematoxylin selama 20 detik dan Eosin selama 20 detik memberikan hasil yang paling baik dibandingkan lama waktu lainnya sehingga didapatkan hasil preparat yang lebih baik.
\end{abstract}

Keyword : Hematoxylin, Eosin, Staining, Jaringan Hati

\section{Pendahuluan}

Jaringan merupakan sekumpulan sel yang tersimpan dalam suatu kerangka struktur atau matriks yang mempunyai suatu kesatuan organisasi yang mampu mempertahankan keutuhan dan penyesuaian terhadap lingkungan diluar batas dirinya (Bevelander, 1998). Saat ini praktikum dan penelitian di bidang histologi menggunakan preparat jaringan organ untuk pengamatan. Tahap pembuatan preparat histologi hewan adalah fiksasi, dehidrasi, clearing, parafinisasi, embedding (penanaman), deparafinisasi, dan staining.

Tahap akhir pembuatan preparat histologi adalah staining. Staining merupakan proses pewarnaan jaringan. Staining bertujuan untuk memudahkan pengamatan menggunakan mikroskop dan membedakan bagian-bagian jaringan yang akan diamati seperti inti sel, sitoplasma, dan lain-lain.

Dalam penelitian ini stain yang digunakan adalah Hematoksilin-Eosin.

Pada tahap staining digunakan waktu yang berbeda-beda antara satu proses dengan proses lainnya. Waktu baku yang digunakan sesuai dengan literatur (buku atau jurnal) yang digunakan sebagai pedoman staining. Namun pada aplikasinya, waktu baku tidak dapat dijadikan pedoman pada semua jenis jaringan yang diwarnai, salah satunya hati. Jaringan hati yang diwarnai dengan menggunakan waktu baku memiliki intensitas warna yang tinggi sehingga sulit diamati bagian-bagian jaringan yang diinginkan.

Oleh karena itu, , dilakukan penelitian ini untuk mengetahui waktu yang tempat dalam staining atau pewarnaan jaringan hati. Diharapkan dengan diketahuinya waktu staining yang tepat dapat memudahkan mahasiswa dalam praktikum dan penelitian yang berkaitan dengan histologi.

\section{Metode Penelitian}

Penelitian ini menggunakan metode Deskriptif dengan tiga perlakuan berdasarkan waktu pewarnaan Hematoksilin-Eosin, yaitu :

$\begin{array}{lll}\text { Perlakuan I } & : & \text { Hematoksilin } 2 \text { menit dan } \\ & \text { Eosin 2 menit } \\ \text { Perlakuan II } & : \begin{array}{l}\text { Hematoksilin 1 menit dan } \\ \text { Eosin 1,5 menit }\end{array} \\ \text { Perlakuan III : } \begin{array}{l}\text { Hematoksilin 20 detik dan } \\ \text { Eosin 20 detik }\end{array}\end{array}$




\subsection{Pembuatan Preparat Histologis Hati}

Pembuatan preparat histologis diawali dengan isolasi organ hati. Organ direndam dalam larutan fisiologis selama beberapa saat sebelum dipindahkan ke dalam larutan Bouin's dan dibiarkan selama 18-20 jam lalu dilanjutkan dengan proses dehidrasi sampel dalam alkohol bertingkat dimulai dari konsentrasi $70 \%$ hingga $100 \%$ yang disusul dengan penjernihan (Clearing) menggunakan xylol. Setelah proses penjernihan (Clearing) selesai, maka hati ditanam (embedding) dalam parafin $56-58^{\circ} \mathrm{C}$. Hati yang telah ditanam kemudian disayat dan ditempel pada kaca objek yang telah dilapisi oleh Meyer's Albumin. Sayatan yang ditempel dibiarkan beberapa waktu kemudian diwarnai dengan menggunakan Hematoxylin Eosin Stain (McManus dan Mowry, 1960).

\subsection{Pengamatan}

Pengamatan dilakukan dengan membandingkan preparat jaringan hati yang diwarnai berdasarkan waktu pewarnaan Hematoksilin-Eosin yang berbeda dan diamati di bawah mikroskop dengan perbesaran 40x dan 100x.

\section{Hasil dan Pembahasan}

Berdasarkan penelitian yang telah dilakukan, diketahui bahwa perlakuan waktu yang berbeda pada pewarnaan Hematoksilin-Eosin memberikan hasil yang berbeda. Secara morfologi, preparat jaringan hati yang telah diwarnai memperlihatkan intensitas warna yang berbeda (gambar 1).

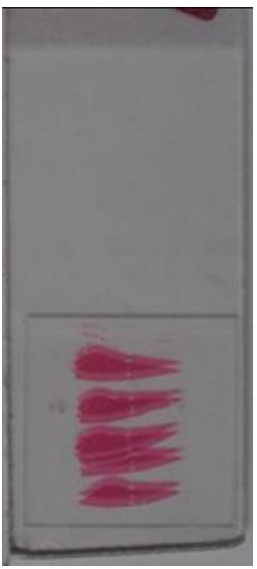

(a)

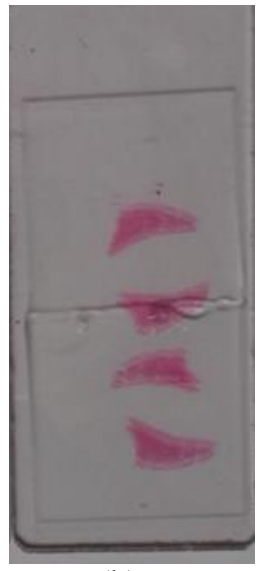

(b)

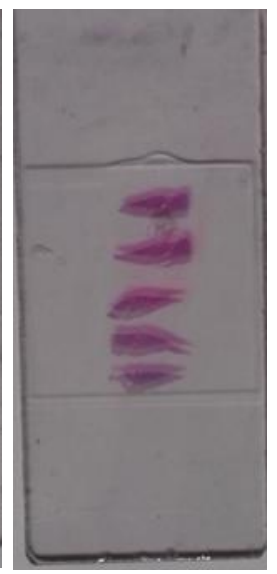

(c)
Gambar 1. Preparat Jaringan Hati (a) Perlakuan I, (b) Perlakuan II, (c) Perlakuan III.

Pada gambar 1 memperlihatkan bahwa pada perlakuan I intensitas warna merah lebih mendominasi jaringan karena pewarnaan Eosin. Warna Hematoksilin ditutupi oleh warna Eosin. Pada perlakuan II memperlihatkan bahwa intensitas warna dari masing-masing zat warna telah mulai berkurang. Namun, warna merah masih mendominasi jaringan. Pada perlakuan III memperlihatkan bahwa intensitas warna dari masing-masing zat warna telah mulai berkurang, warna ungu dari Hematoksilin dan merah dari Eosin terlihat jelas.

Hematoksilin-Eosin bersifat basa yang khusus mewarnai unsur asam pada sel sehingga tampak kebiruan, karena unsur yang paling asam ialah asam deoksiribonukleat (DNA) dan asam ribonukleat (RNA), maka inti dan lingkungan sitoplasma yang banyak terdapat ribosom akan tampak berwarna biru tua, sehingga disebut basofilik. Eosin bersifat asam yang mewarnai unsur basa dari sel sehingga tampak merah muda, karena banyak bagian sitoplasma yang bersifaft basa, pada daerah tertentu sitoplasma terwarna merah muda, unsur-unsur ini disebut asidofilik (eosinofilik) (Setiawan, 2016).

Secara Histologi, perlakuan waktu masingmasing zat warna memperlihatkan perbedaan yang jelas. Pada perlakuan I memperlihatkan bahwa jaringan hati didominasi oleh warna merah seperti terlihat pada gambar 2 sehingga inti sel dan sitoplasma sulit dibedakan.

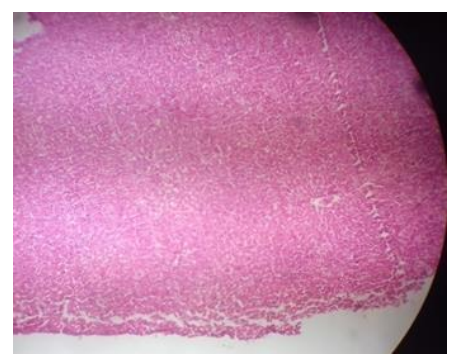

(a)

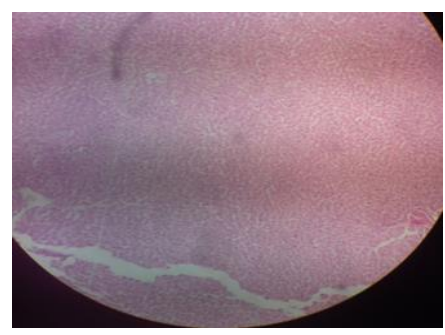

(b)

Gambar 2. Preparat Jaringan Hati (a) Perlakuan I perbesaran 40x, (b) Perlakuan I perbesaran 100x.

Pada perlakuan II memperlihatkan bahwa secara histologi preparat jaringan hati yang diwarnai mulai memperlihatkan perbedaan antara inti sel dan sitoplasma yang diwarnai. Pada gambar 3 memperlihatkan bahwa inti sel yang berwarna ungu mulai tampak dan tersebar di seluruh permukaan jaring. 


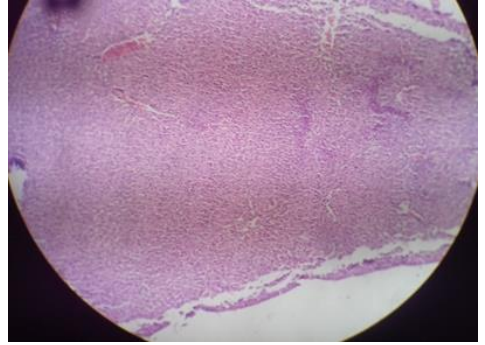

(a)

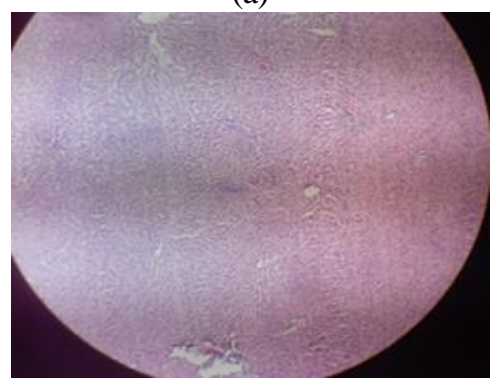

(b)

Gambar 3. Preparat Jaringan Hati (a) Perlakuan II perbesaran 40x, (b) Perlakuan II perbesaran 100x.

Namun pada perlakuan ini, warna dari hematoksilin dan eosin masih cukup pekat sehingga inti sel dan sitoplasma pada jaringan masih sulit dibedakan.

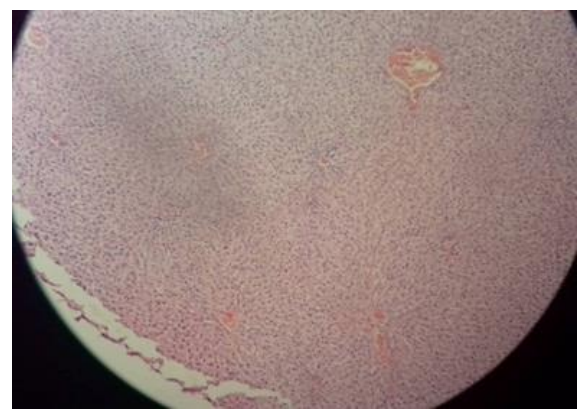

(a)

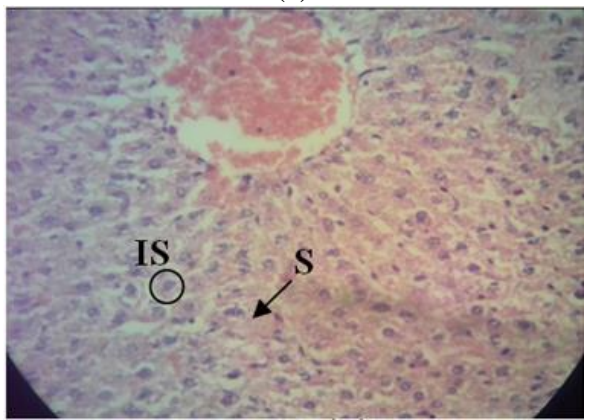

(b)

Gambar 4. Preparat Jaringan Hati Perlakuan III, (a) Perbesaran 100x, (b) Perbesaran 400x. (Ket. IS : Inti Sel, S : Sitoplasma)

Berdasarkan uraian di atas dapat diketahui bahwa waktu yang tepat untuk waktu pewarnaan Hematoksilin-Eosin pada histologi hati adalah perlakuan III (gambar 4), yaitu Hematoksilin 20 detik dan Eosin 20 detik. Perlakuan III pada pewarnaan ini memberikan hasil yang maksimal sehingga dapat memudahkan dalam pengamatan dengan menggunakan mikroskop. Dengan diketahui waktu tepat untuk pewarnaan Hematoksilin-Eosin ini, maka ini dapat digunakan dalam praktikum dan penelitian terkait histologi hati dimana hasil yang didapatkan dapat menjadi lebih baik dibandingkan sebelumnya.

\section{Kesimpulan}

Berdasarkan hasil yang didapatkan, dapat disimpulkan bahwa :

1. Waktu yang tepat pada proses staining preparat jaringan hati adalah perlakuam III, yaitu Hematoksilin 20 detik dan Eosin 20 detik.

2. Penentuan waktu tepat pada pewarnaan Hematoksilin-Eosin ini dapat memudahkan mahasiswa dalam proses staining dan dapat memberikan hasil yang maksimal dibandingkan sebelumnya.

\section{Daftar Pustaka}

Bevelander, G. And Ramaley. 1988. Dasar-Dasar Histologi Edisi Kedelapan. Erlangga. Jakarta.

Jusuf, A.A. 2009. Histoteknik Dasar. UI Press. Jakarta.

McManus, J.F.A. dan R.W. Mowry. 1960. Histologic and Histochemical. Paul B. Hoeber Inc. Alabama

Setiawan, B. 2016. Optimalisasi Metode Automatic Slide Stainer untuk Pewarnaan Jaringan Menggunakan Haematoksilin-Eosin. Laporan Akhir Penelitian Pembinaan Bagi Tenaga Fungsional Non Dosen : Hal 1-2. 